\author{
А. М. Кузнецов \\ Даугавпилсский университет \\ (Даугавпилс, Латвия) \\ anatolijs.kuznecovs@du.lv
}

\title{
УПОТРЕБЛЕНИЕ УКАЗАТЕЛЬНЫХ МЕСТОИМЕНИЙ ९Ь, ТЪ, ОНЪ В ЗОГРАФСКОМ ЕВАНГЕЛИИ
}

В старославянском языке три указательных местоимения, в отличие от тех же местоимений реконструируемого праславянского языка, уже не были связаны какимлибо отношением с лицом участников диалога. В присубстантивной позиции сь в диалоге обычно указывает на предмет, находящийся перед глазами и в центре внимания, a TZ - на отсутствующий предмет, т. е. становится анафорическим, онZ сохраняется в некоторых устойчивых сочетаниях типа на онъ полz. В роли субстантивов те же местоимения сочетали в себе указательную функцию и функцию 3-его лица. Их форма И. падежа окончательно вытеснила местоимение * ${ }^{2} / \mathfrak{t a} / \mathbf{t e}$, дейктическая функция закрепилась за местоимением сь, а анафорическая реализовалась всеми тремя, но в сочетании с разными союзами - а сь, н сь, н тz, онz жє. В косвенных падежах они использовались в случае противопоставления нескольких предметов, вне противопоставления сохранялись косвенные падежи анафорического местоимения *н/tr/tr.

Ключевые слова: старославянский язык, указательные местоимения, диалог, нарратив, анафора.

В старославянской системе мы находим три указательных местоимения сь, тZ, oнz. К ним примыкают еще местоимение овz, которое использовалось обычно в перечислительных конструкциях с сопоставительным значением овZ... овъ/Ароугzін, и анафорическое местоимение *н/ı/ı. Указательная функция нормально реализуется в присубстантивной позиции в ситуации диалога. Но дейктическая функция, как указывали уже античные авторы, плавно перетекает в анафорическую, если объектом указания является не присутствующий предмет, а то, что следует искать в речевом потоке [Бюлер 1993: 109-114]. В таком случае указательные местоимения совершают экспансию в сферу действия анафорического местоимения *н/ı/ı. Действительно, использование последнего в присубстантивной позиции представляло уже редкие случаи в славянской речи [Кузнецов, Иорданиди, Крысько 2006: 81-90]. 
Самым трудным является вопрос о первоначальных семантических различиях трех указательных местоимений. Считается, что система указания в некоторых индоевропейских языках была трехстепенная, например, в латинском: «Ніс есть указательное местоимение п ер в о го л и ца; оно указывает на предмет, близкий говорящему по месту или времени или только что упомянутый. По-русски ему соответствует этот. Часто оно подходит по значению к словам: мой, наш. <..> Iste есть указательное местоимение в торого лица; оно указывает на предмет, находящийся перед говорящим. По-русски ему соответствует этот (иногда тот). Часто подходит по значению к словам: $m b l$, вbl, mвой, ваш. < ..> Ille есть указательное местоимение третьего л ица; оно указывает на предмет, отдаленный от говорящего по месту или времени или упомянутый раньше» [Соболевский 1998: 372-375].

Такую же систему исследователи видят и в праславянском: сь — 'этот, ближайший предмет и предмет в отношении к говорящему лицу', тz — 'тот предмет и предмет в отношении ко 2-ому лицу', онъ - 'тот, вне отношения к говорящим' [Мейе 1951: 353-354]. Однако как соотносится эта гипотетическая система с системой местоимений в старославянских памятниках, пока остается неясным.

Что касается латинского местоимения iste, то В.Н. Топоров доказал у этого местоимения изначальность значения 'тот самый, именно тот' и его происхождение из соединения двух местоимений *is-to- (ср. славянское прилагательное нстұн 'истинный, настоящий') [ЭССЯ 8: 246-247]. Уцелевшие редкие примеры употре-

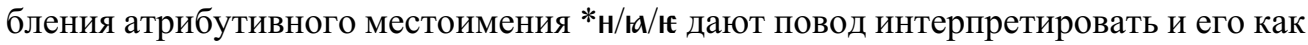
'этот самый, вот этот'. Например, в приписке дьякона Григория к Остромирову евангелию в молитвенной части (диалогической в начале) используется указатель-

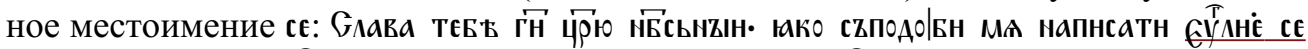
$<\ldots>$ Naпнсахz же eV̂. Evं

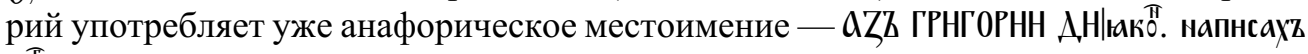

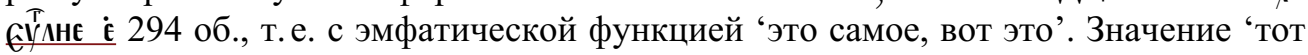
самый’ обнаруживается и у местоимения тъ (см. примеры ниже).

\section{1. Присубстантивная позиция ${ }^{1}$}

Анализ употребления указательных местоимений в присубстантивной позиции в Зографском евангелии показал, что указание не связано с отношением к лицу участников диалога, как это предполагается для праславянского периода (сь $\leftrightarrow$ azZ, TZ $\leftrightarrow$ TZI, OHZ $\leftrightarrow *^{*}$ ), ср.:

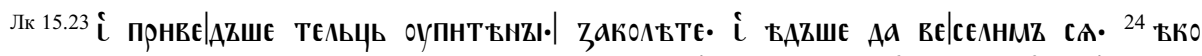

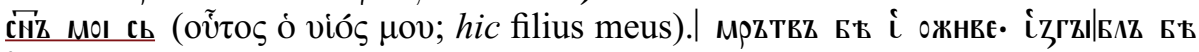
i оврьте $\mathbf{C A}^{2}$,

\footnotetext{
1 Здесь в сокращении представлен материал публикации [Кузнецов 2018].

2 В цитатах опущены некоторые диакритические знаки.
} 


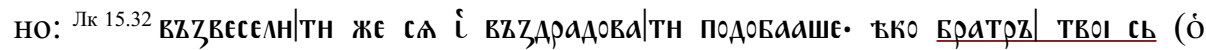

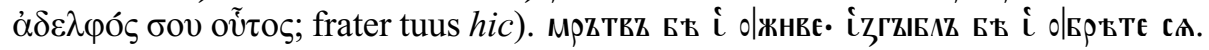

На самом деле в обоих случаях местоимение указывает на предмет в центре внимания не только говорящего, но и слушателей.

Не наблюдается и обязательной зависимости от греческого оригинала, т. е. рас-

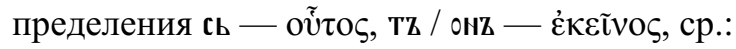

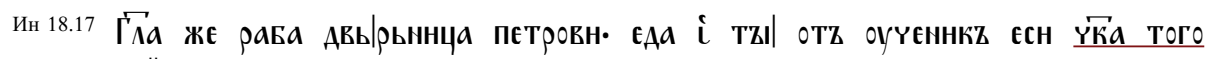

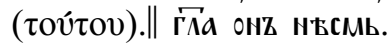

В центре внимания может оказаться любой присутствующий предмет:

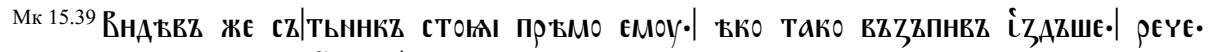

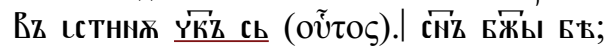

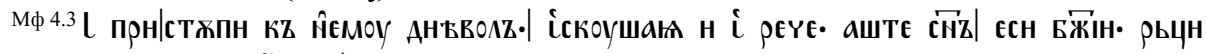

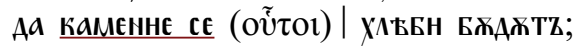

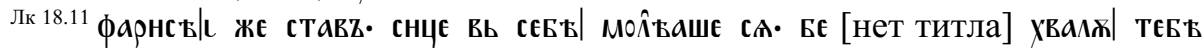

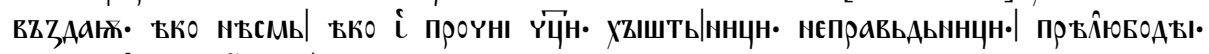

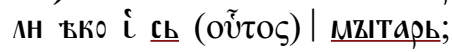

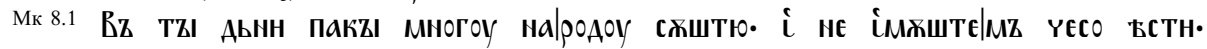

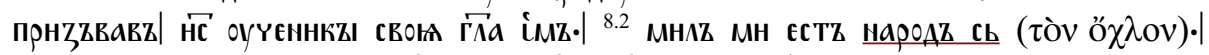

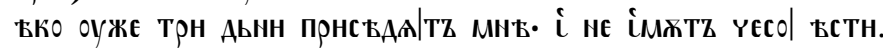

Это же местоимение используется в ситуациях, когда интересующий говорящих предмет не находится перед глазами. В таких случаях дейксис переходит в анафору - отсылку к предтексту, что особенно заметно в отречении Петра, где используется придаточное определительное с местоимением нже:

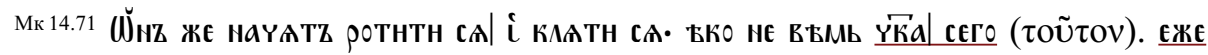

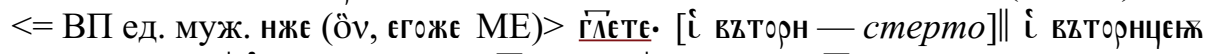

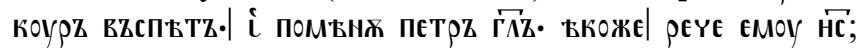

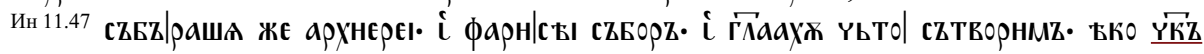

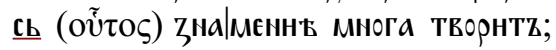

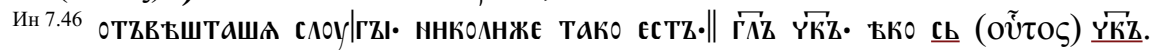

Предмет может быть и неконкретным:

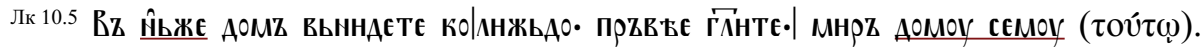

В таких же контекстах отмечается и местоимение тъ:

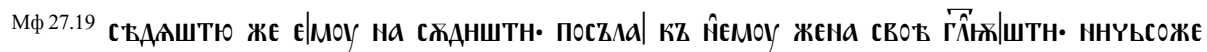

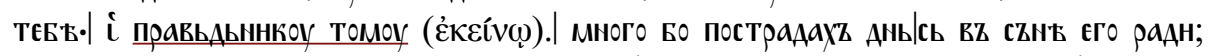

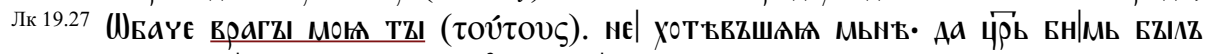

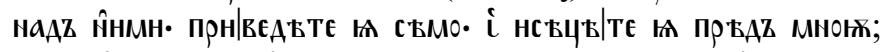

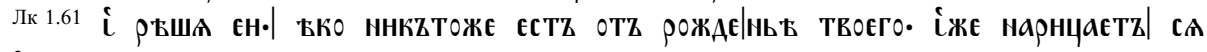
iMEHEML TظML $(\tau O V ́ \tau \omega)$; 


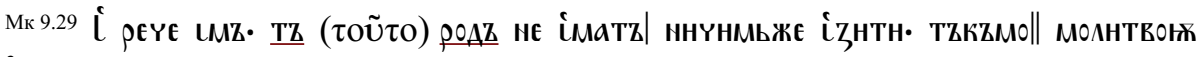
i noc TOML.

В монологической речи чаще всего встречается соединение местоимения тъ с местоимением нже в определительном придаточном:

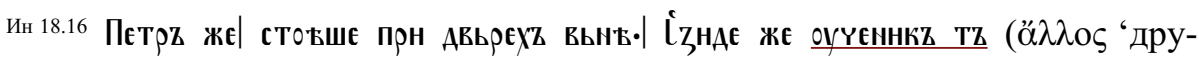

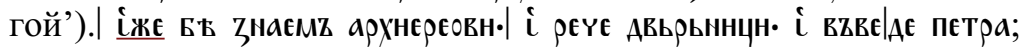

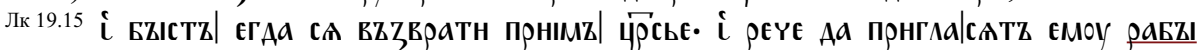

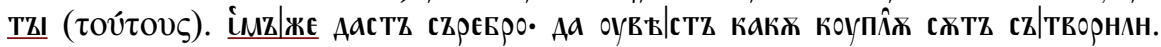

Что касается употребления в диалоге атрибутивного oнz, то отмечен единственный пример, где местоимение относится к отсутствующему предмету и является анафорическим:

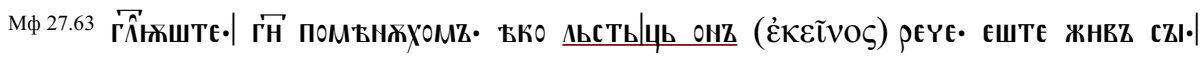
По трьХZ АньХZ вZСТАнж.

Таким образом, все три местоимения в таких контекстах конкурируют, но онz уже уходит из употребления.

В собственно указательном значении местоимение онz отмечается только во фразеологических сочетаниях пространственного значения, причем в монологических частях евангельского текста, где субъектом ориентации является Иисус:

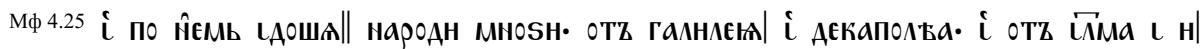

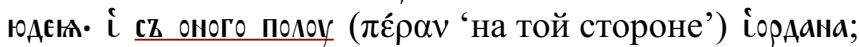

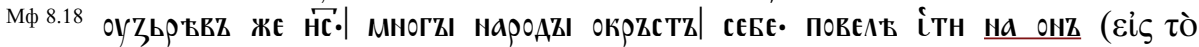
$\pi \varepsilon \rho \alpha \nu$ 'нна противоположный берег’) | полz;

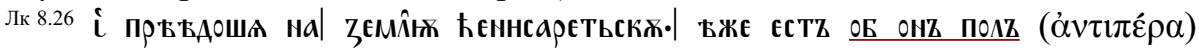
Галн|АеІА;

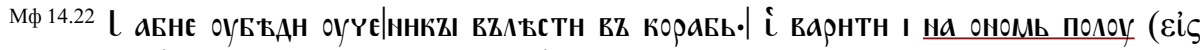

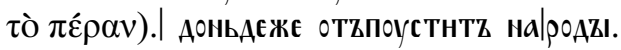

Примеры с темпоральным значением также допускают взаимозамену всех трех анафорических местоимений в монологических контекстах:

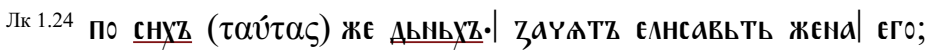

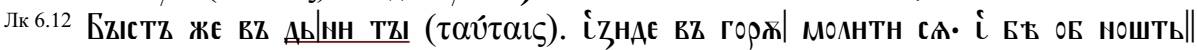

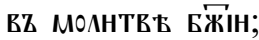

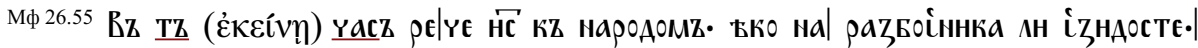

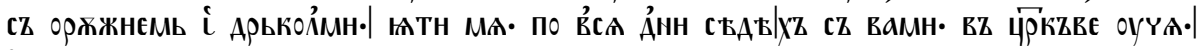
i He HCTE MENE;

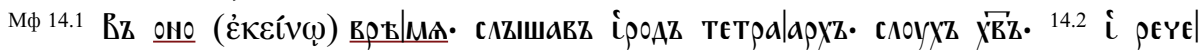

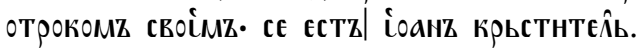

Особый случай представляют примеры, где греческое местоимение $\alpha$ $\tau o ́ \varsigma$ 'сам, тот самый’, т. е. выделительно-отождествительное, переведено славянским местоимением тz. Чаще всего эти приметы содержат темпоральные существительные: 


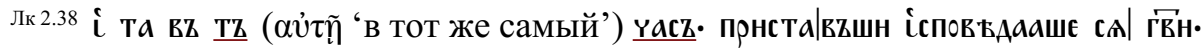

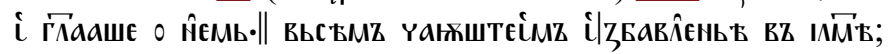

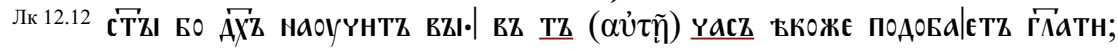

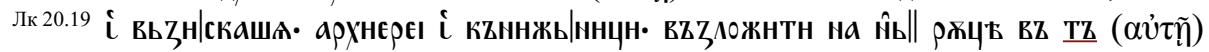

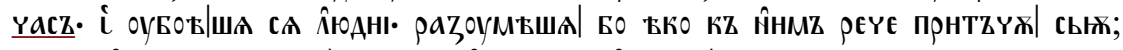

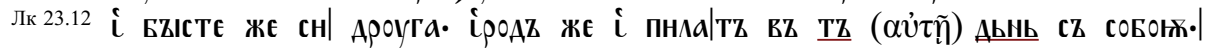
ПрБЖАЕ БО ББашеТЕ вра|ЖАЖ іМЖШТА МЕЖАН со|БОю;

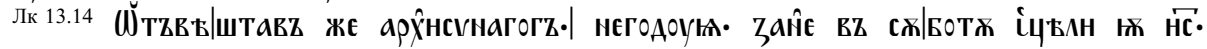

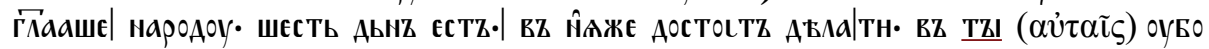
ПРНХОАА|ШТТ ЦБАНТЕ СА• а НЕ ВZ АЬ|НЬ СХБОТZНZІ

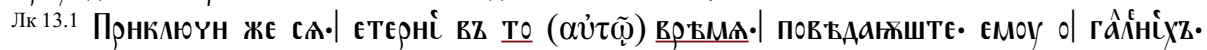
іхzже крz|вь пнтьтz [! т.е. Пилат]- сzмьсь сz| жрzтвамн іхz.

Реже местоимение относится к абстрактным существительным и названиям человека:

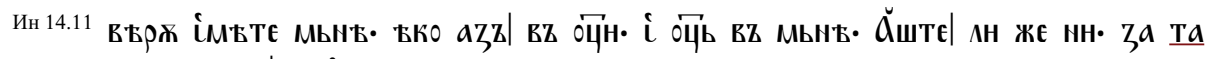

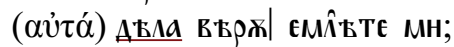

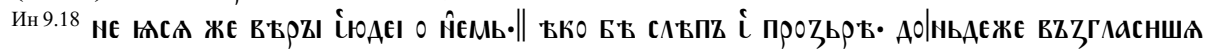

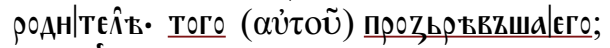

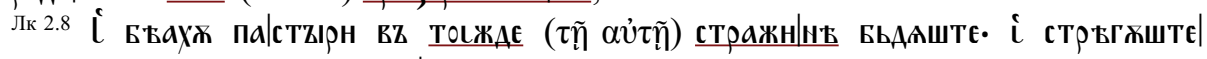
стражж ноштьнжњљ. о стаАБ| свосмь.

Особенно интересны сочетания с именем собственным:

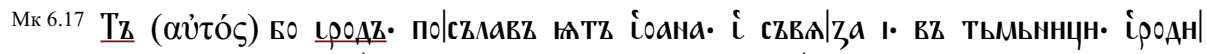
БАZI раАН. ЖенZІ фНАнПа| Братра своеГО. БКО ОЖенН СА.| ЕН;

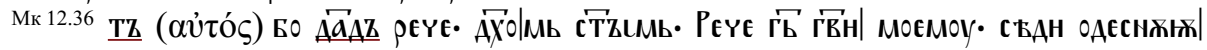

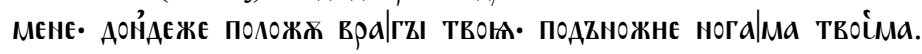

Подобное употребление местоимения тъ известно и в древнерусских деловых текстах, ср. в Грамоте Мстислава Владимировича и его сына Всеволода 1130 г.:

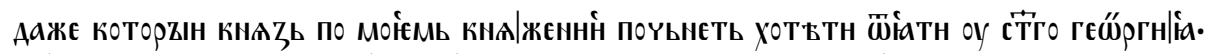

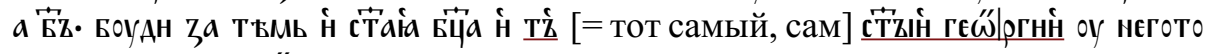
$<=$ у которого $>$ б̈тнмають 5-8;

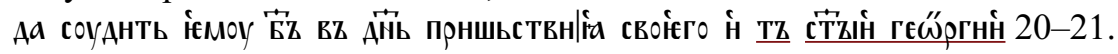

Наконец, местоимение сь может использоваться в перечислительно-сопоставительных конструкциях в соединении с другими местоимениями:

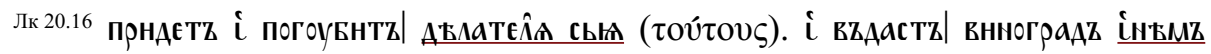

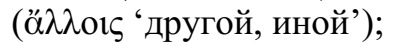

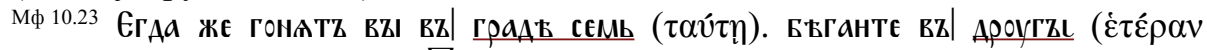

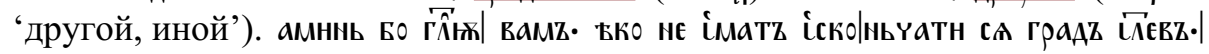
АОНАЕЖЕ ПРНАЕТZ С̈Z| ҮСКZL. 


\section{2. Позиция субстантива}

Если же указательные местоимения занимают место существительного, то они начинают выполнять одновременно с указательной и функцию местоимения третьего лица, т.е. относятся к лицу или предмету, не участвующему в диалоге. А в монологическом тексте, где дейктическая функция полностью преобразуется в анафорическую, они не могут занимать начальную позицию, здесь они появляются только после соответствующего существительного. Именно в субстантивной роли указательные местоимения начинают конкурировать с анафорическим местоимением $*_{\mathbf{H}} / \mathbf{r a} / \mathbf{l t}$.

В диалогическом тексте местоимение-субстантиват сь возможно в начальной позиции. Именно здесь оно сохраняет свою дейктическую функцию, если предмет указания присутствует в данной ситуации и находится в центре внимания или уже отсутствует, но остается в центре внимания.

В вопросительном предложении относительно местоимения-подлежащего сь

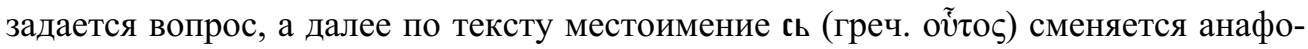

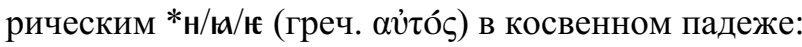

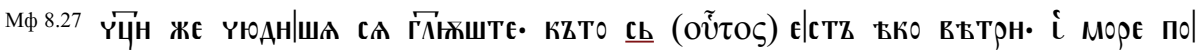

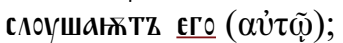

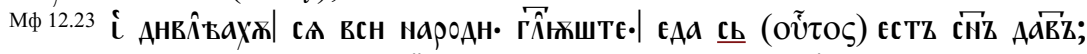

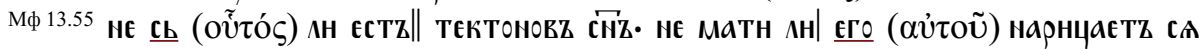

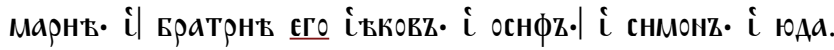

Во всех примерах местоимение сь можно передать по-русски словом этот. В таких контекстах складывается супплетивная пара сь/:єro.

Она дополняется отношением сь/єгоже:

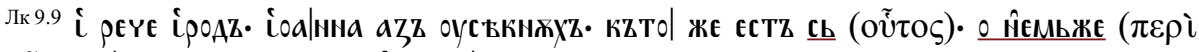

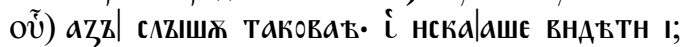

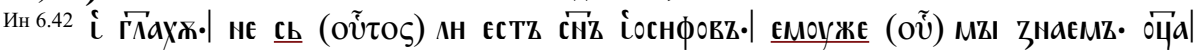

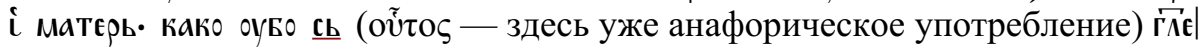
TZ - вKO CZ HCE CZHHAZ;

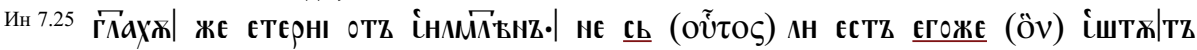
OУБHTH.

С указательной функцией в прямой речи местоимение сь используется и в повествовательных предложениях:

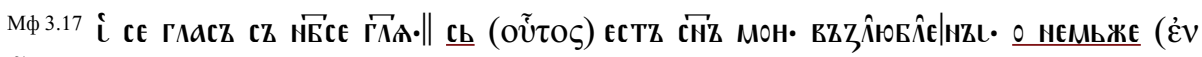
(ீ) БлаговнАнхZ;

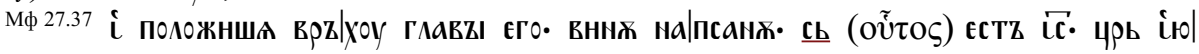
A ŁLCKZ;

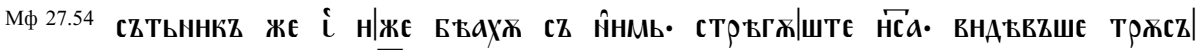

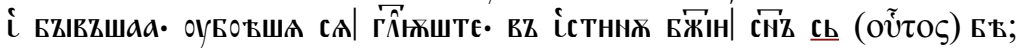




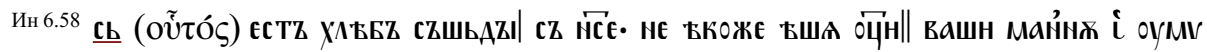
РВШША॰ БААН ХАББZ СЬ ЖНВZ БЖ|АЕТZ ВZ ВЪКZ;

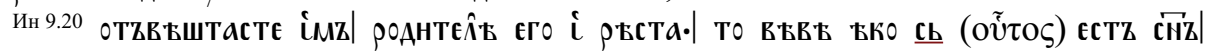

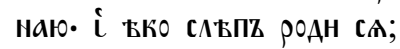

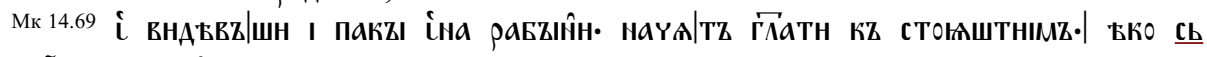

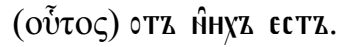

Если же предмет оказывается уже определенным, то у указательного местоимения сь или тъ на первый план выходит анафорическая функция 3-его лица 'он':

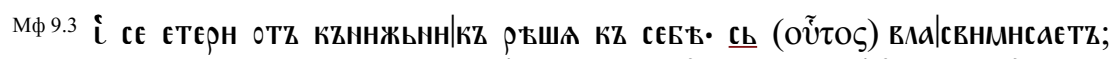

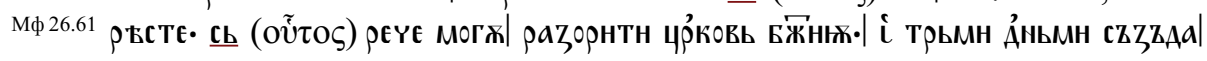
TH $\mathbf{1 \%}$;

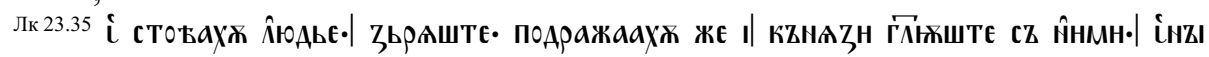

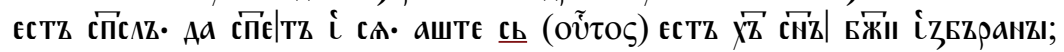

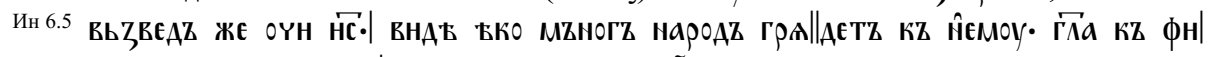

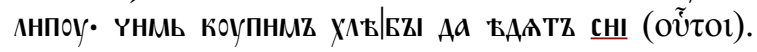

Если предмет отсутствует перед глазами участников диалога, но является уже

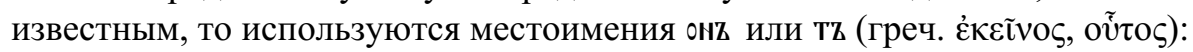

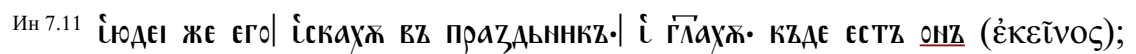

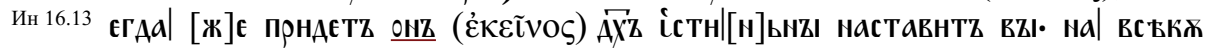

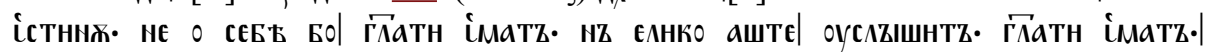

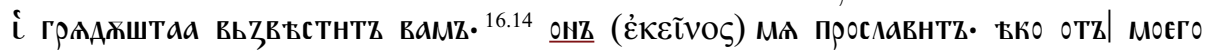

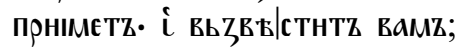

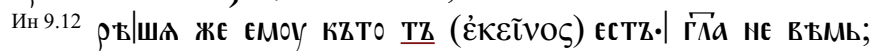

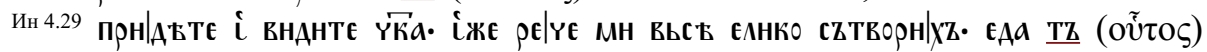

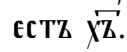

Ср. пример, где сначала используется указательное сь в указательно-анафорической функции, а затем усилительно-отождествительное тъ 'это именно он; он самый’ в отношении того же лица:

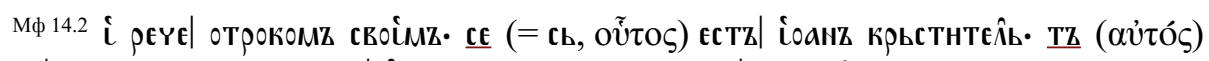

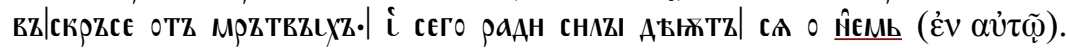

Но даже в ситуации, где речь идет о двух разных лицах, возможно использование одного и того же местоимения сь:

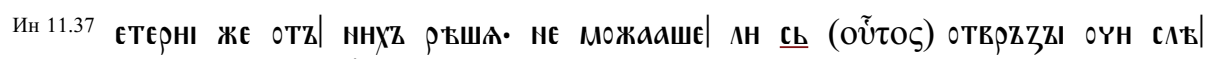

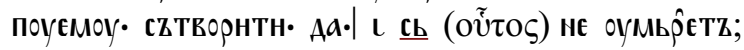

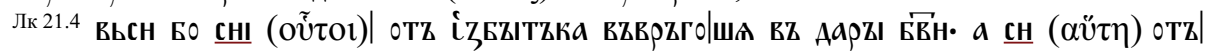

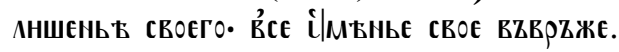

В местоименно-соотносительных конструкциях гораздо чаще, чем пара сь-нжє

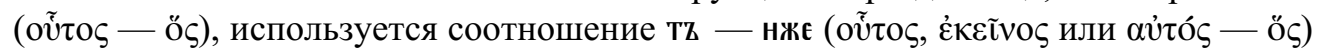
или тъ - членное причастие: 


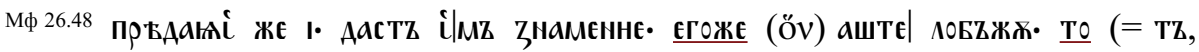

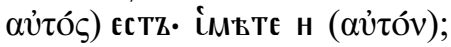

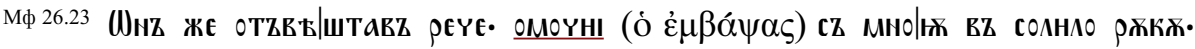

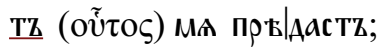

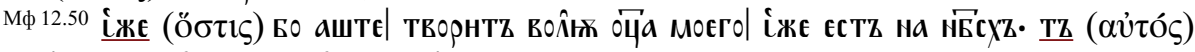
Бра|ТZ Мон. i сестра. i мТТн е|стZ;

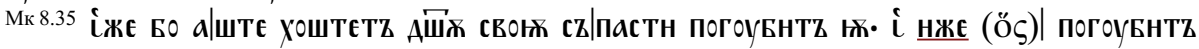

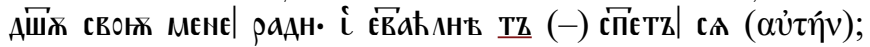

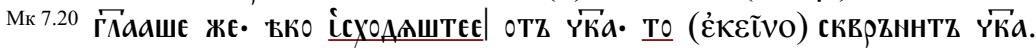

Лицо, о котором говорится, может быть как конкретным и определенным, так и неконкретным и неопределенным. Местоимение тъ чаще оказывается в постпозиции к нже или к причастию. Ср. соединение двух конструкций, вложенных одна в другую:

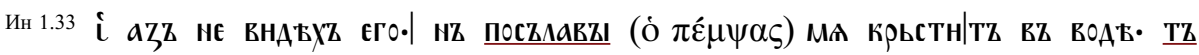

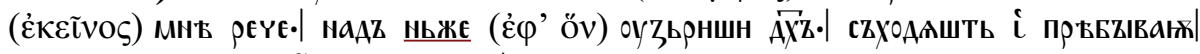

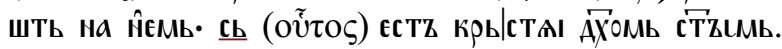

В нарративной части текста все три указательных местоимения используются в анафорической функции. В интродуктивных контекстах:

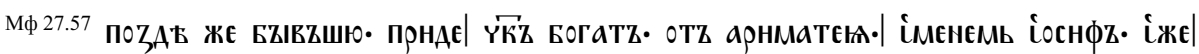

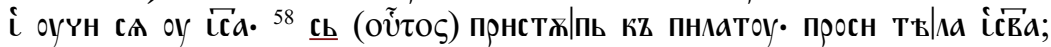

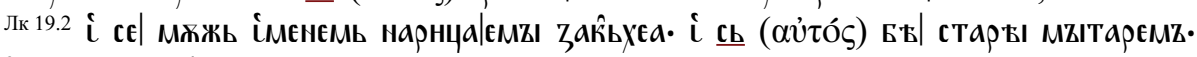

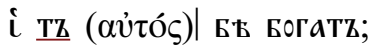

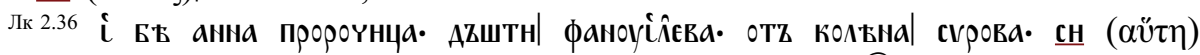

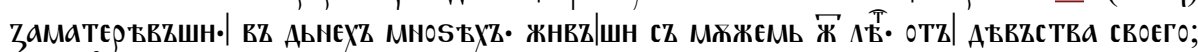

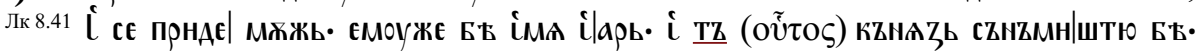

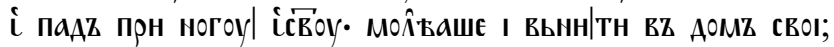

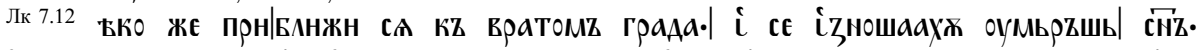

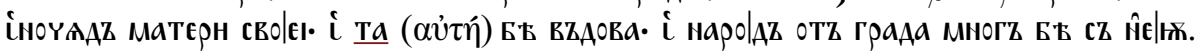

В сопоставительных контекстах 'народ - субъект':

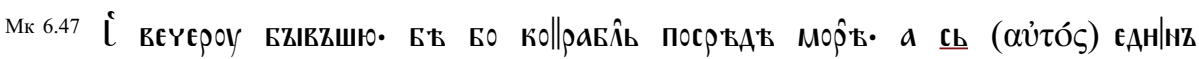
на Zемі̂ि;

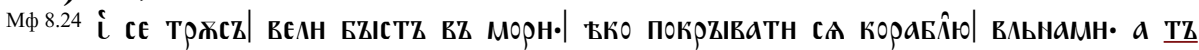

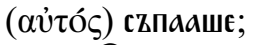

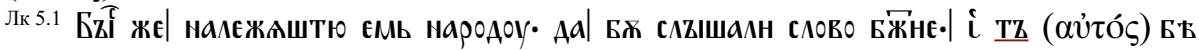
стон прн еZерь ћенн|саретьсц:;

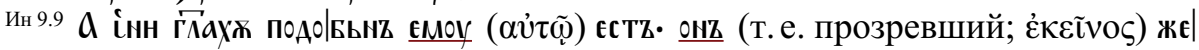
ГКаше вко аZZ есмь;

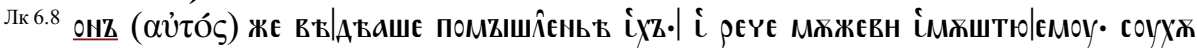

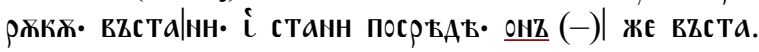

Стоит отметить, что в сочетаниях с сочинительными союзами местоимения особым образом распределяются: а сь, н сь, н тZ, онz же. 
В повествовательных контекстах в последовательности «существительное анафорическое местоимение»:

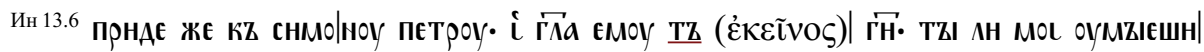
NOZ $\mathbf{k}$;

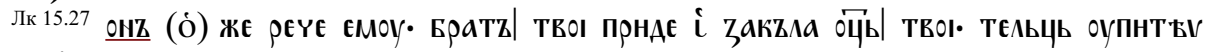
HZI•| ТКО СZАрава I ПрНІаTZ;

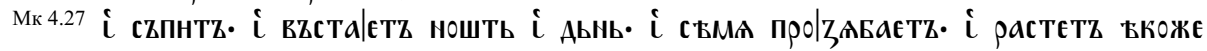

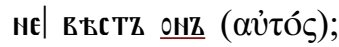

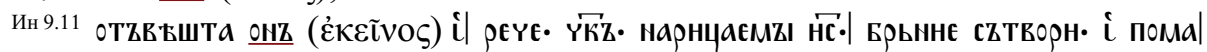
Zа OYH MH;

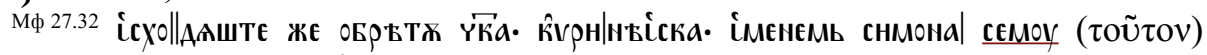
ZаАБша Понестн ќрств| его;

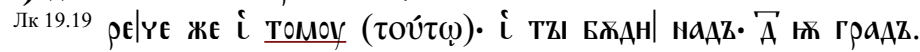

В сопоставлении нескольких субъектов могут использоваться пары тъ - сь, Tz - onz, личные местоимения и тz — onz. Здесь наблюдаем и формы косвенных падежей всех трех местоимений:

Ин 6.29 (ОТZ|вБШТТА Н̈

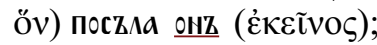

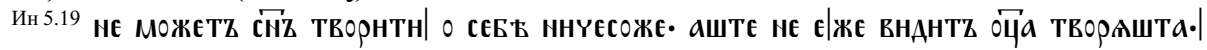

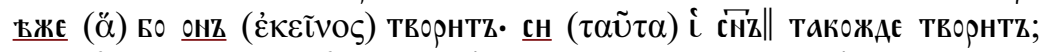

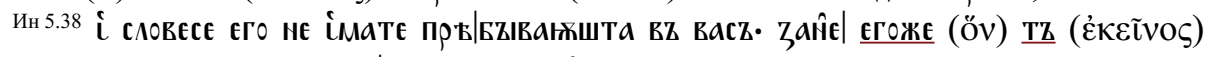

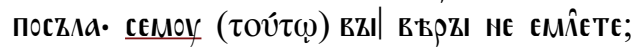

Ин 21.21 сеГО (

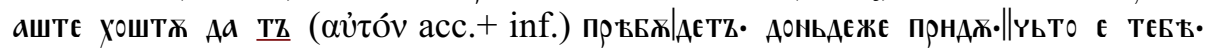
ПО MHЕ ТZI ГРААН;

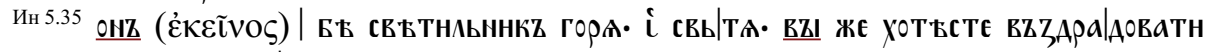

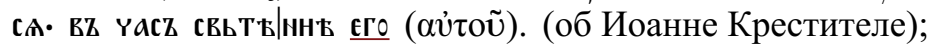

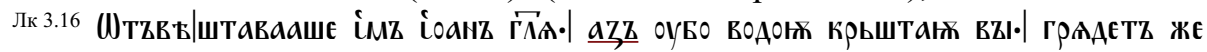

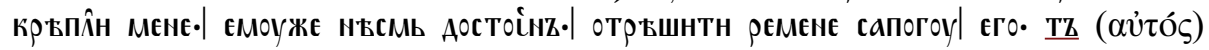

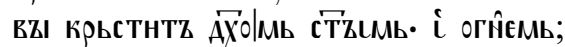

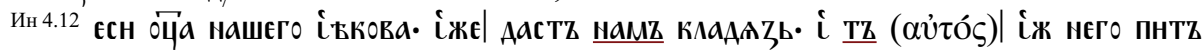

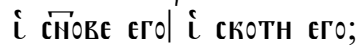

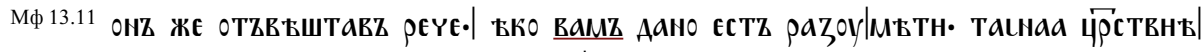

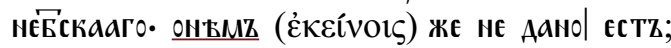

Ин 7.27 HZ сего ( HE ВЪСТZ| ОТZКЖАОУ ЕСТZ;

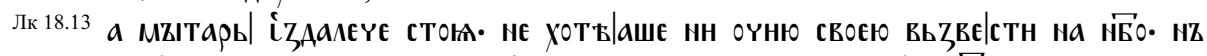

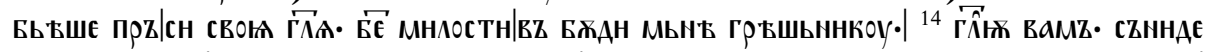

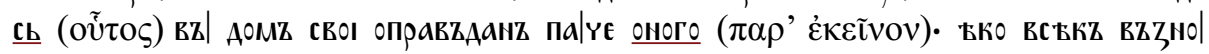

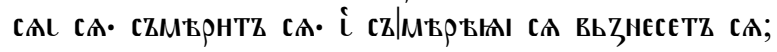




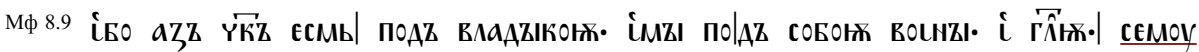

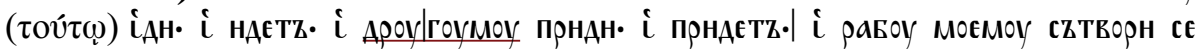
(

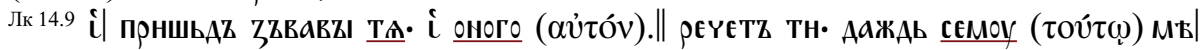

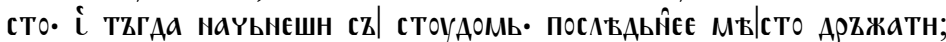

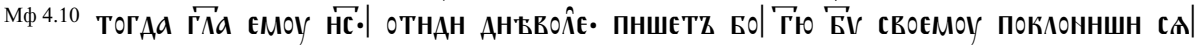

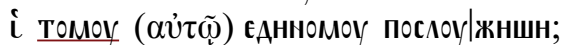

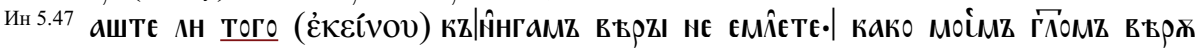
í|METE;

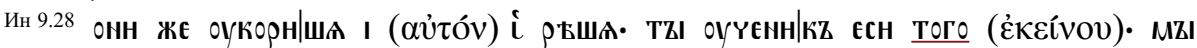
МОС ВОВН| ЕСМZ ОУҮЕННЦН.

Таким образом, в переводе Евангелия местоимения сь, TZ, онz в атрибутивной позиции используются в указательной и анафорической функциях и имеют полную парадигму, причем употребление местоимения oнz уже резко сокращено до устойчивых словосочетаний. В субстантивной роли они сохраняют указательное значение в диалогическом режиме, однако противопоставление между ними базируется не на корреляции с личными местоимениями и вполне свободно от греческой системы местоимений. Обычно для указания на лицо или предмет, присутствующий в ситуации диалога, используется местоимение сь, а об отсутствующем говорится Tz или onz. В нарративном режиме все три местоимения выполняют анафорическую функцию и являются взаимозаменимыми. Однако если речь идет о нескольких сопоставляемых объектах, то данные местоимения регенерируют свое указательное значение, создавая пары сь — онz/тz. Что касается местоимения онz, то его косвенные падежи продолжают использоваться только в сопоставительных контекстах, вне этих контекстов употребительна только форма И. падежа.

\section{Словари}

ЭССЯ - Этимологический словарь славянских языков. Праславянский лексический фонд. Выпуск 8 (*ха-*јьvьlga). М., 1981.

\section{Литература}

Бюлер К. Теория языка. Репрезентативная функция языка. М., 1993.

Кузнецов А. Употребление указательных местоимений сь, тъ, онъ в присубстантивной позиции в Зографском евангелии // Valoda-2018. Valoda dažādu kultūru kontekstā. XXVIII Zinātnisko rakstu krājums. Daugavpils, 2018. С. 31-37. Доступно на сайте: https://du.lv/wp-content/uploads/2019/02/Valoda_2018_DRUKA_GALA.pdf

Кузнецуов А. М., Иорданиди С. И., Крысько В.Б. Прилагательные // Историческая грамматика древнерусского языка. Т. III. М., 2006.

Мейе А. Общеславянский язык. М., 1951.

Соболевский С. И. Грамматика латинского языка: Часть теоретическая. Морфология и синтаксис. СПб., 1998. (Фототипическое изд.: М., 1948). 


\author{
Anatoly M. Kuznetsov \\ Daugavpils University \\ (Daugavpils, Latvia) \\ anatolijs.kuznecovs@du.lv
}

\title{
THE USE OF DEMONSTRATIVE PRONOUNS $S b, T \mathrm{~T}, \mathrm{ONZ}$ IN CODEX ZOGRAPHENSIS
}

The three demonstrative pronouns in Old Church Slavonic, in contradistinction to the same pronouns in reconstructed Common Slavic, were already in no way connected to the participants of a dialogue. The attributive pronoun $s b$ usually indicates a present object in the centre of attention, whereas the pronoun $t \mathrm{t}$ indicates an absent object and functions anaphorically. The pronoun on $b$ is used only in idiomatic constructions - e.g. na onz polb. The pronouns used as substantives have two functions - one deictic and the other as a third-person marker. Their nominative fully replaced the nominative of the pronoun $* j b / j a / j e$. The pronoun $s b$ reserved its deictic function in dialogue, but all three pronouns had an anaphoric function, though only in combination with different conjunctions - asb, $i s b, i t z$, on $\check{z} e$. The forms of oblique cases are used when several objects stood in opposition to one another; otherwise, the oblique cases of the pronoun * jb/jal je are preserved.

Keywords: Old Church Slavonic, demonstrative pronouns, dialogue, narrative, anaphora.

\section{References}

Bühler K. Teoriya yazyka. Reprezentativnaya funktsiya yazyka. Moscow, 1993.

Kuznetsov A. Upotreblenie ukazatel'nykh mestoimenii $s b$, $t z$, on $b$ v prisubstantivnoi pozitsii v Zografskom yevangelii. Valoda-2018. Valoda dažădu kultūru kontekstā. XXVIII Zinātnisko rakstu krājums. Atb. red. S. Polkovnikova. Daugavpils: Saule, 2018. C. 31-37 [https://du.lv/wp-content/uploads/2019/02/Valoda_2018_DRUKA_GALA. pdf].

Kuznetsov A., Iordanidi S.I., Krys'ko V.B. Istoricheskaya grammatika russkogo yazyka. Prilagatel'nye. Vol. III. Pod red. V. B. Krys'ko. Moscow, 2006.

Meillet A. Obshcheslav'anskii yazyk. Moscow, 1951.

Sobolevskii S.I. Grammatika latinskogo yazyka: Chast' teoreticheskaya. Morfologiya i sintaksis. St. Petersburg, 1998. (Fototipicheskoe izd. Moscow: Izd-vo literatury na inostrannykh yazykakh, 1948). 